\title{
Production level, fertility, health traits, and longevity in local and commercial dairy breeds under organic production conditions in Austria, Switzerland, Poland, and Sweden
}

\author{
Anna Bieber, ${ }^{1 *}$ Anna Wallenbeck, ${ }^{2,3}$ Florian Leiber, ${ }^{1}$ Birgit Fuerst-Waltl, ${ }^{4}$ Christoph Winckler, ${ }^{4}$ \\ Patricia Gullstrand, ${ }^{2}$ Jacek Walczak, ${ }^{5}$ Piotr Wójcik, ${ }^{5}$ and Anet Spengler Neff ${ }^{1}$ \\ ${ }^{1}$ Department of Livestock Sciences, Research Institute of Organic Agriculture (FiBL), 5070 Frick, Switzerland \\ ${ }^{2}$ Department of Animal Breeding and Genetics, Swedish University of Agricultural Sciences (SLU), 75007 Uppsala, Sweden \\ ${ }^{3}$ Department of Animal Environment and Health, Swedish University of Agricultural Sciences (SLU), 53231 Skara, Sweden \\ ${ }^{4}$ University of Natural Resources and Life Sciences Vienna (BOKU), 1180 Vienna, Austria \\ ${ }^{5}$ National Research Institute of Animal Production, 32-083 Balice, Poland
}

\section{ABSTRACT}

Our aim was to map the performance of local (native) dairy cattle breeds in Austria, Switzerland, Poland, and Sweden with regard to production, fertility, longevity, and health-associated traits and to compare them with commercial (modern) breeds. For this purpose, we analyzed test-day records (July 1, 2011, to June 30, 2014) and treatment records (Austria, Sweden) of cows managed on organic farms. We performed country-wise comparisons of 123,415 lactations from Original Braunvieh $(\mathrm{OB})$ and Grey Cattle (AL) with Braunvieh (BV; Brown Swiss blood $>60 \%$ ) in Switzerland; AL with BV (Brown Swiss blood $>50 \%$ ) in Austria; Polish Black and White (ZB), Polish Red and White (ZR), and Polish Red (RP) with Polish Holstein Friesian (PHF) in Poland; and Swedish Red (SRB) with Swedish Holstein (SH) in Sweden. Average milk yields were substantially lower for local compared with commercial breeds in all countries; differences ranged from $750 \mathrm{~kg}$ (Sweden) to $1,822 \mathrm{~kg}$ (Austria), albeit on very different average levels. Local breeds showed a longer productive lifetime by $0.64,0.83,1.42$, and 0.20 lactations in Switzerland, Austria, Poland, and Sweden, respectively, again on very different levels in each country. Regarding fertility traits, calving interval was shorter in local than in commercial breeds by 13 (Sweden), 14 (Switzerland), and $20 \mathrm{~d}$ (Austria, Poland). Insemination index was lower in certain local breeds by 0.15 (Switzerland), 0.14 (Austria), 0.21 (Poland), and 0.13 (Sweden). Several local breeds showed a lower proportion of cows with $>100,000$ somatic cells $/ \mathrm{mL}$. This was the case in Switzerland (OB 24.2\%; BV 35.8\%), Austria (AL 25.3\%;

Received December 11, 2018.

Accepted February 6, 2019.

*Corresponding author: anna.bieber@fibl.org
BV 36.9\%), and Sweden (SRB 42.4\%; SH 43.4\%). In contrast, the respective proportion in Poland exceeded $82 \%$ in all breeds except the commercial PHF (76.1\%). In Sweden, lactations with veterinary treatments were considerably less prevalent in SRB (15.6\%) than in SH $(21.7 \%)$. In Austria, breeds differed only in treatments for udder disorders, which favored AL. In conclusion, the markedly lower milk yields of local breeds are partly counterbalanced by (somewhat inconsistent) advantages in longevity, fertility, and health traits across 4 European countries. This indicates that the robustness of local breeds can contribute to improved sustainability of organic dairy systems.

Key words: organic agriculture, local dairy breed, robustness, longevity

\section{INTRODUCTION}

Organic dairy systems are characterized by a strong dependency on local feed resources, higher shares of pasture-based feeding, and lower amounts of concentrate feeding, as well as stronger restrictions regarding medical drug use (EC, 2007). Therefore, cows with a high genetic production potential as selected over the last decades under high-input conditions (Ingvartsen et al., 2003; Knaus, 2009) may not perform as well under organic conditions. Moreover, high production levels are known to be accompanied by declines in terms of health, fertility, and longevity (Knaus, 2009; Stiglbauer et al., 2013). Genetic antagonisms between production and different functional traits, such as fertility (e.g., Kelm et al., 2000; Pritchard et al., 2013; Berry et al., 2014) and disease incidences of different health problems (e.g., Ingvartsen et al., 2003; Oltenacu and Broom, 2010; Pritchard et al., 2013), have been reported in studies and reviews, including critical discussion of variations and inconsistencies between studies (e.g., Oltenacu and Broom, 2010; Berry et al., 2014). 
Lower-yielding dairy cows can show greater resistance to disease than high-yielding dairy cows intensively selected for production, especially with regard to udder health, fertility, longevity, and metabolic disorders (e.g., Bytyqi et al., 2005; Gandini et al., 2007; Curone et al., 2016, 2018).

Consequently, organic standards indirectly or explicitly recommend the use of local breeds, for example, by stating that "the choice of breeds should take account of their capacity to adapt to local conditions" (EC, 2007). Nevertheless, several studies have revealed that dairy breeds on organic farms do not differ substantially from those on conventional farms: Holstein Friesian (HF) cattle with high genetic merit for milk production are widespread on many organic farms across Europe (Nauta et al., 2005, the Netherlands; Marley et al., 2010, United Kingdom; Ivemeyer et al., 2018, Germany; Krieger et al., 2017, Germany, France, Spain, and Sweden). The preference for certain cattle breeds and crossbreds is linked to the management intensity and farm type. For instance, Nauta et al. (2009) found that farmers of specialized and high-input farms prefer HF cows or their crosses, whereas low-input farmers and those classified as multifunctional due to a higher diversification of their farm business preferred native Dutch breeds.

Several studies have compared dairy cattle breeds from different populations or strains with different genetic merits for milk production and fertility under low-input or grassland-based production conditions without focusing on organic farming (e.g., Macdonald et al., 2008; Coleman et al., 2009, 2010). Others have explicitly investigated differences between organic and conventional farms but usually without differentiating between breeds (e.g., Ahlman et al., 2011).

Studies on organic farmers' breeding goals show slightly higher importance given to fertility-, udder-, and longevity-related traits compared with breeding goals of conventional farmers (Bapst et al., 2005, Switzerland; Simianer, 2007, Germany; Ahlman et al., 2014, Sweden). For example, Ahlman et al. (2014) reported that Swedish organic dairy producers tended to give higher preference to disease resistance, including mastitis resistance, than conventional producers, whereas Slagboom et al. (2016) reported that Danish organic farmers with only Holstein cows gave highest preference to improving cow fertility followed by milk production and calf mortality.

To develop sustainable animal breeding strategies, it is essential to broaden the definition of breeding goals by balancing productivity with functional traits such as health and fertility (Olesen et al., 2000; Fuerst-Waltl et al., 2016) and by choosing appropriate dairy breeds as a preventive health strategy for organic dairy sys- tems (Marley et al., 2010). Regarding the latter, it is necessary to gain knowledge of the actual performance of dairy cows, including local breeds managed under organic conditions. Therefore, we aimed to assess the performance of local breeds compared with commercial dairy breeds on organic farms in Austria, Switzerland, Sweden, and Poland with regard to production level, fertility, longevity, and health-associated traits.

\section{MATERIALS AND METHODS}

\section{Data}

Data for this study originated from cows lactating from July 1, 2011, to June 30, 2014, and managed under organic farming conditions. The data set contained 123,415 test-day records from Swiss, Austrian, Polish, and Swedish farms. Veterinary treatment records of 6,908 and 59,878 lactations of Austrian and Swedish cows, respectively, were also analyzed.

A detailed overview on number of herds, cows and lactations by country, including distributions over lactations and proportion of lactation records obtained from cows managed under mountainous grazing conditions per breed within country, is provided in Table 1 .

In Switzerland, the competence center for informatics and genetics of Swiss breeding organizations, Qualitas AG (Zug, Switzerland) provided test-day records for the 2 dual-purpose local breeds, Grey Cattle (AL) and pure Original Braunvieh (OB), which we compared with the commercial dairy breed Braunvieh (BV) with at least 60\% Brown Swiss (BS) blood. Organic herds were identified via a list provided by the federation of organic farmers in Switzerland, Bio Suisse (Basel, Switzerland). Because a study comparing data on SNP of Grey Cattle of Swiss and Austrian origin concluded that distinction of animals by national origin is not possible at the molecular level (C. Drögemüller, University of Bern, Bern, Switzerland, unpublished data), we decided to code both breeds identically as AL. The Brown Cattle population consists of 3 subpopulations, the Original Braunvieh (OB), the US-Brown Swiss (BS), and Braunvieh (BV), the latter being a cross of OB and BS (Hagger, 2005). Recent genetic studies show clearly separated clusters for $\mathrm{OB}$ and $\mathrm{BV}$ in terms of genetic distances (Signer-Hasler et al., 2017). Given the fact that we chose high thresholds of Brown Swiss blood in Swiss and Austrian data, we coded both commercial Brown Cattle populations as BV, assuming similar populations in both countries.

In Austria, the local dual-purpose breed Tyrolean Grey Cattle (AL) was compared with BV with at least $50 \%$ BS blood. The data set was provided by ZuchtData EDV-Dienstleistungen GmbH (Vienna, Austria), which 


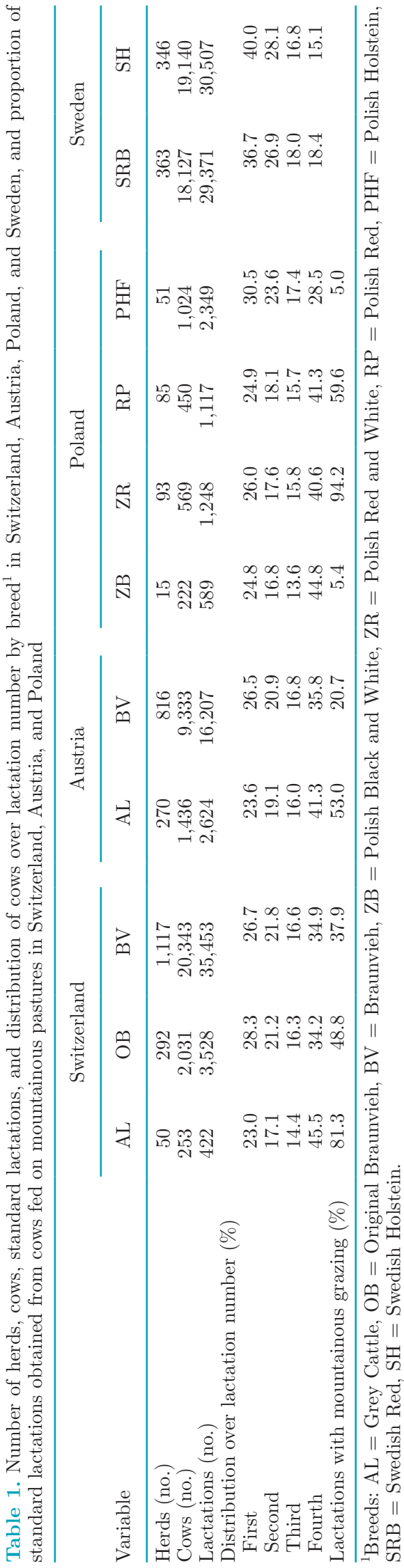

is a subsidiary company of the Federation of Austrian Cattle Breeders, ZAR (Vienna, Austria).

The Polish data set was provided by the Polish nationwide system for the dairy cattle breeding evaluation, SYMLEK, owned by the Polish Federation of Cattle Breeders and Dairy Farmers (Warsaw, Poland). It contained records from 3 local breeds: Polish Red (RP), which is an old local breed, now representing less than $1 \%$ of the Polish dairy population, Polish Black and White (ZB), and Polish Red and White (ZR), which both had herdbooks installed in 2008 and are old compact dual-purpose cow types with less than $50 \%$ Holstein genes (PFHBiPM, 2018). These 3 local breeds were compared with the commercial Polish Holstein Friesian (PHF) dairy breed.

The Swedish data set was provided by the Swedish Official Milk Recording Scheme, Växa (Uppsala, Sweden), containing records from the local breed Swedish Red (SRB) and the commercial breed Swedish Holstein $(\mathbf{S H})$.

We decided to code the 2 Holstein populations in Poland and Sweden as PHF and SH, respectively, because we assumed that the genetic structure of these populations differs: PHF originates from crossbreeding of traditional Polish ZR and ZB dual-purpose cattle with Holstein Friesian (PFHBiPM, 2018), whereas $\mathrm{SH}$ originates from the breed Svensk Laglandsboskap (SLB, previously called Swedish Friesian), which was extensively crossed with North American Holstein Friesian genes over several decades (Bett et al., 2010).

\section{Traits Investigated}

Milk yield was corrected to a fat content of $4.0 \%$ and a protein content of $3.4 \%$ (i.e., ECM) by applying the following formula (Heller and Potthast, 1990):

$$
\begin{gathered}
\mathrm{ECM}(\mathrm{kg})=\operatorname{milk}(\mathrm{kg}) \times[0.38 \times(\text { fat \% }) \\
+0.21 \times(\text { protein } \%)+1.05] / 3.28
\end{gathered}
$$

Further production traits investigated were milk protein and milk fat contents (\%).

Data on lifetime production (LIFEPROD; $\mathrm{kg}$ of ECM) and productive lifespan (LIFESPAN; number of lactations) were limited to cows culled within the study period. Data on LIFEPROD were not available for Sweden and Poland.

Fertility traits investigated were days open, calving interval (days), and number of inseminations until conception. The proportion of records of the first 9 testday records per lactation having SCC $>100,000$ cells/ $\mathrm{mL}$ of milk (SCC100) was used as an indicator for subclinical mastitis (Hamann, 2005). 
Data on veterinary treatments were only available for Austria and Sweden and coded as binary variables (yes or no) at the lactation level for treatment of udder (UDDER) and fertility disorders (FERT), metabolic diseases (META), and any veterinary treatment (VET). Austrian data contained veterinary claw treatment data (TRCLAW), whereas remarks on claw condition at trimming (yes/no, RECLAW) were analyzed in the Swedish data set. Austrian data on veterinary treatments originated from the Austrian health monitoring program, as described by Egger-Danner et al. (2012), and the Swedish data originated from the Swedish Official Milk Recording Scheme (Växa Sverige, 2015).

Only completed lactations with calving and drying off within the study period were included. The accepted interval for milk yield of standard lactations was 500 to $22,000 \mathrm{~kg}$ of ECM, 1.5 to $9.0 \%$ for milk fat content, and 1.0 to $7.0 \%$ for milk protein content. If one of the production measures exceeded the limits, all records from that lactation were discarded. The fertility records were restricted to the following intervals: 250 to $700 \mathrm{~d}$ for calving interval, 20 to $400 \mathrm{~d}$ for days open, and 1 to 8 for number of inseminations. Valid data for SCC100 had to range from 0 to $100 \%$, and for the binary traits (UDDER, FERT, META, VET, TRCLAW, and RECLAW), only 0 and 1 were accepted as valid entries.

\section{Statistical Analysis}

Swiss, Austrian, and Polish Data. Differences between dairy breeds were analyzed using linear mixed effects models for the traits ECM, milk protein, fat content, days open, and calving interval, and mixed effects logistic regression models for the trait SCC100 with logit link and binomial distribution; for the traits VET, UDDER, FERT, META, TRCLAW with a negative binomial distribution; and with Poisson distribution for number of inseminations applying the lme4 package (Bates et al., 2015) in the $\mathrm{R}$ environment (versions 3.2.4 and 3.2.5; R Core Team, 2016).

Austrian and Polish data sets were analyzed separately using model [1] and Swiss data sets using model $[2]:$

$$
\begin{gathered}
\mathrm{Y}_{\mathrm{ijklmno}}=\mu+\mathrm{b}_{\mathrm{i}}+\mathrm{l}_{\mathrm{j}}+\mathrm{yr}_{\mathrm{k}}+\mathrm{se}_{\mathrm{l}}+\text { mount }_{\mathrm{m}} \\
+\operatorname{herd}_{\mathrm{n}}+\operatorname{cow}_{\mathrm{o}}\left(\operatorname{herd}_{\mathrm{n}}\right)+\mathrm{e}_{\mathrm{ijklmno}},
\end{gathered}
$$

where $\mathrm{Y}_{\mathrm{ijklmno}}$ is the response variable; $\mu$ = overall mean; $b_{i}=$ fixed effect of breed i (i for Austria $=A L$ or BV, and for Poland $=\mathrm{ZB}, \mathrm{ZR}$, RP, or PHF, respectively); $\mathrm{l}_{\mathrm{j}}=$ fixed effect of lactation $\mathrm{j}(\mathrm{j}=1,2,3$, or $\geq 4) ; \mathrm{yr}_{\mathrm{k}}$
$=$ fixed effect of year of calving $\mathrm{k}(\mathrm{k}=2011-2014) ; \mathrm{se}_{\mathrm{l}}$ $=$ fixed effect of calving season $\mathrm{l}(\mathrm{l}=$ quarter $1,2,3$ or 4$) ;$ mount $_{\mathrm{m}}=$ fixed effect of mountainous grazing $\mathrm{m}$ $(\mathrm{m}=$ yes or no $) ; \operatorname{herd}_{\mathrm{n}}=$ random effect of herd $\mathrm{n}$; $\mathrm{cow}_{\mathrm{o}}$ $\left(\operatorname{herd}_{\mathrm{n}}\right)=$ random effect of cow o nested within herd $\mathrm{n}$; and $\mathrm{e}_{\mathrm{ijk} k \mathrm{mno}}=$ random error.

$$
\begin{aligned}
& \mathrm{Y}_{\mathrm{ijklmnop}}=\mu+\mathrm{b}_{\mathrm{i}}+\mathrm{l}_{\mathrm{j}}+\mathrm{yr}_{\mathrm{k}}+\mathrm{se}_{\mathrm{l}}+\text { mount }_{\mathrm{m}} \\
& + \text { zone }_{\mathrm{n}}+\operatorname{herd}_{\mathrm{o}}+\operatorname{cow}_{\mathrm{p}}\left(\operatorname{herd}_{\mathrm{o}}\right)+\mathrm{e}_{\mathrm{ijklmnop}},
\end{aligned}
$$

where $\mathrm{Y}_{\mathrm{ijklmnop}}$ is the response variable; $\mu=$ overall mean; $b_{i}=$ fixed effect of breed i $(i=A L, O B$, or BV); $\mathrm{l}_{\mathrm{j}}=$ fixed effect of lactation $\mathrm{j}(\mathrm{j}=1,2,3$, or $\geq 4) ; \mathrm{yr}_{\mathrm{k}}$ = fixed effect of year of calving $\mathrm{k}(\mathrm{k}=2011-2014) ; \mathrm{se}_{\mathrm{l}}$ $=$ fixed effect of calving season $\mathrm{l}(\mathrm{l}=$ quarter $1,2,3$, or 4$) ;$ mount $_{\mathrm{m}}=$ fixed effect of mountainous grazing $\mathrm{m}$ $(\mathrm{m}=$ yes or no $) ;$ zone $_{\mathrm{n}}=$ fixed effect of zone $\mathrm{n}(\mathrm{n}=$ valley region, mountain region 1 , mountain region 2 , mountain regions 3 and 4 ); herd ${ }_{\circ}=$ random effect of herd $\mathrm{o} ; \operatorname{cow}_{\mathrm{p}}\left(\mathrm{herd}_{\mathrm{o}}\right)=$ random effect of cow p nested within herd $\mathrm{o}$; and $\mathrm{e}_{\mathrm{ijk} k \mathrm{mnop}}=$ random error.

The models to analyze LIFESPAN and LIFEPROD only included the fixed effect of breed and the random effect of herd. Visual inspection of residual plots did not reveal an obvious deviation from homoscedasticity or normality, except for the variables days open and calving interval, which were therefore log-transformed before analysis. Post hoc analysis to identify breed differences was performed as Tukey contrast using the lsmeans package (Lenth, 2016); results were back transformed for logistic regressions before presentation.

Swedish Data. We used SAS software (version 9.4; SAS Institute Inc., Cary, NC) for the statistical analyses of Swedish data sets. Differences between breeds in milk production (ECM), milk protein and fat contents, days open, calving interval, number of inseminations, and SCC100 were analyzed with mixed linear models in the HPMIXED procedure using model [3]. The binary health-related traits UDDER, FERT, META, VET, and RECLAW were analyzed with generalized linear models in the GLIMMIX procedure using model [3] with logit link and binomial distribution:

$$
\begin{aligned}
& \mathrm{Y}_{\mathrm{ijklmn}}=\mu+\mathrm{b}_{\mathrm{i}}+\mathrm{l}_{\mathrm{j}}+\mathrm{yr}_{\mathrm{k}}+\mathrm{se}_{\mathrm{l}} \\
& +\operatorname{herd}_{\mathrm{m}}+\operatorname{cow}_{\mathrm{n}}\left(\operatorname{herd}_{\mathrm{m}}\right)+\mathrm{e}_{\mathrm{ijk} k \mathrm{mn}},
\end{aligned}
$$

where $Y_{\mathrm{ijklmn}}=$ response variable; $\mu=$ overall mean; $b_{\mathrm{i}}$ $=$ fixed effect of breed $\mathrm{i}(\mathrm{i}=\mathrm{SRB}$ or $\mathrm{SH}) ; \mathrm{l}_{\mathrm{j}}=$ fixed effect of lactation $\mathrm{j}(\mathrm{j}=1,2,3$, or $\geq 4) ; \mathrm{yr}_{\mathrm{k}}=$ fixed effect of year of calving $\mathrm{k}(\mathrm{k}=2011-2014) ; \mathrm{se}_{1}=$ fixed effect of calving season $\mathrm{l}(\mathrm{l}=$ quarter $1,2,3$, or 4$)$; $\operatorname{herd}_{\mathrm{m}}=$ random effect of herd $\mathrm{m} ; \mathrm{cow}_{\mathrm{n}}\left(\operatorname{herd}_{\mathrm{m}}\right)=$ random effect 
of cow $\mathrm{n}$ nested within herd $\mathrm{m}$; and $\mathrm{e}_{\mathrm{ijklmn}}=$ random error.

The model to analyze LIFESPAN included only the fixed effect of breed and the random effect of herd. Pairwise differences between breeds were analyzed using the LSMEANS statement, and results were back transformed for logistic regressions before results were presented.

Statistical significance was determined at $P<0.05$, with tendency at $P>0.05$ and $<0.1$ in all analyses.

\section{RESULTS}

\section{Production Performance and Longevity}

Average milk production (ECM) per lactation was higher in commercial breeds than in local breeds in all countries, with the difference ranging from $750 \mathrm{~kg}$ of ECM in Sweden to $1,822 \mathrm{~kg}$ of ECM in Austria. Average production levels differed considerably between countries, being highest in Sweden $(\mathrm{SRB}=8,379 \pm$ $54 \mathrm{~kg}$ vs. $\mathrm{SH}=9,129 \pm 54 \mathrm{~kg} ; \mathrm{LSM} \pm \mathrm{SE}$ ) and lowest in Poland $(\mathrm{ZR}=4,375 \pm 114 \mathrm{~kg}, \mathrm{ZB}=4,390 \pm 153$ $\mathrm{kg}, \mathrm{RP}=3,997 \pm 112 \mathrm{~kg}$ vs. $\mathrm{PHF}=4,969 \pm 124 \mathrm{~kg}$; Table 2).

Lifetime production of the commercial breed BV was higher by 6,132 and 4,490 kg of ECM in Switzerland and Austria, respectively, when analyzing data sets from culled cows (Table 3). In contrast, at least one local breed in each country showed a longer productive lifespan. Number of lactations were higher by $0.64,0.83$, 0.20 , and 1.42 for AL in Switzerland and Austria, SRB in Sweden, and ZB in Poland, respectively, although on very different levels in each country (Table 3 ).

Milk protein contents were lower in Austrian and Swiss local breeds (Austria: AL $3.24 \%$ vs. BV 3.30\%; Switzerland: OB $3.25 \%$ vs. BV $3.27 \%$ ), although AL did not differ significantly from BV in Switzerland (AL $3.29 \%$ ). In contrast, local breeds showed higher milk protein contents in Sweden (SRB 3.43\% vs. SH 3.28\%) and Poland (RP $3.32 \%$ vs. PHF $3.12 \%$; Table 2).

Commercial breeds had higher milk fat contents in Switzerland (BV $4.00 \%$ vs. AL 3.74\%) and Austria (BV $4.19 \%$ vs. AL $3.92 \%$ ) but not in Poland and Sweden, where at least one local breed showed higher fat contents than the respective commercial breed (SRB $4.24 \%$ vs. SH $4.01 \%$ for Sweden; RP $4.24 \%$ vs. PHF $4.05 \%$ for Poland; Table 2).

\section{Lactation Persistency}

Data on lactation persistency, defined as the ratio of milk yield from 101 to 200 DIM and milk yield from 1 to 100 DIM, were only available for Switzerland, where

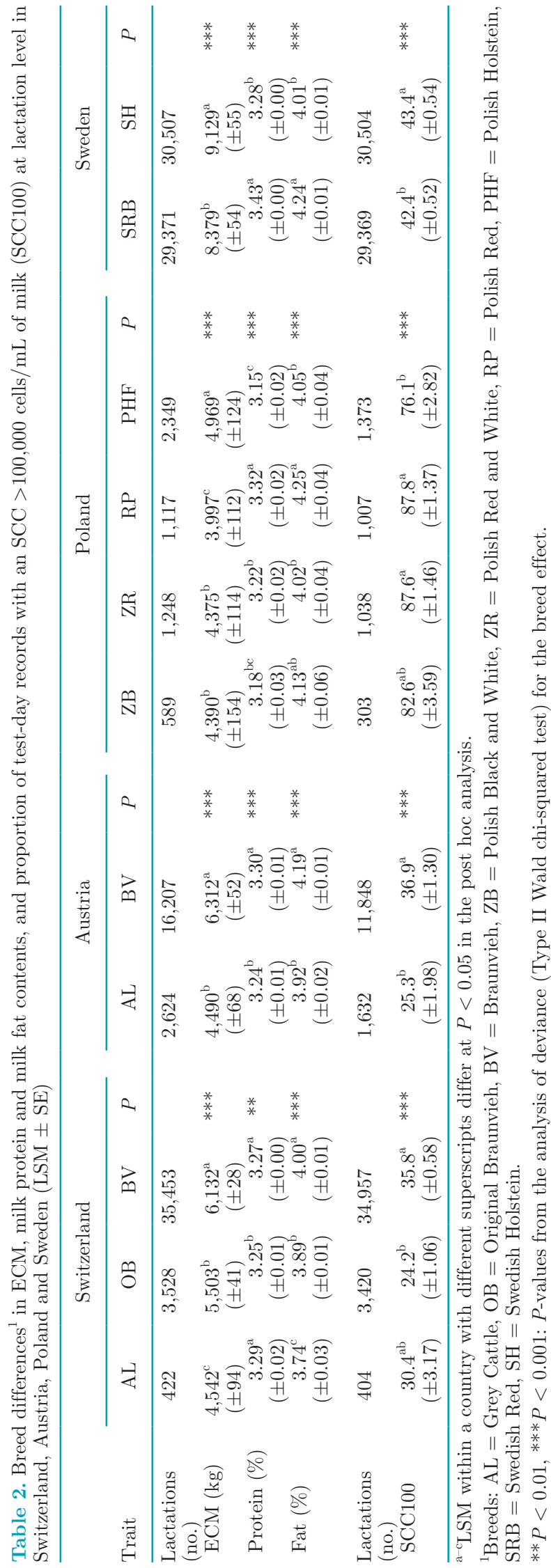

Journal of Dairy Science Vol. 102 No. 6, 2019 
we found the greatest persistency in the local breed OB $(\mathrm{LSM} \pm \mathrm{SE}: 82.8 \% \pm 0.27)$ and the worst in $\mathrm{AL}(78.7 \%$ $\pm 0.70)$ with BV being intermediate $(80.4 \% \pm 0.12)(P$ $<0.001)$.

\section{Fertility Performance}

Our findings on breed comparisons regarding the fertility traits days open, calving interval, and number of inseminations are presented in Table 4. Local breeds showed fewer days open by 5 (OB in Switzerland), 13 (AL in Austria), 21 and 24 ( $\mathrm{ZR}$ and RP in Poland), and 14 (SRB in Sweden) days compared with the respective commercial breeds in all countries. Moreover, local breeds had shorter calving intervals than commercial breeds by $14 \mathrm{~d}$ (AL in Switzerland), $20 \mathrm{~d}$ (AL in Austria), $13 \mathrm{~d}$ (SRB in Sweden), and by 17, 18, and $20 \mathrm{~d}$ (RP, ZR, ZB, respectively, in Poland). Also, the number of inseminations until conception was lower by 0.15 for OB in Switzerland, 0.14 for AL in Austria, 0.21 for ZR in Poland, and 0.13 for SRB in Sweden, respectively, compared with the respective commercial breeds.

SCC

The average proportion of test-day records with SCC $>100,000$ cells $/ \mathrm{mL}$ ranged from 24.2 to $87.8 \%$. It was lowest in Austria and Switzerland and highest (by far) in Poland, with Swedish cows being intermediate (Table 2). The Austrian local breed had a lower SCC100 than the commercial breed (AL $25.3 \%$ vs. BV 36.9\%). The same was true for OB in Switzerland, but AL did not differ significantly from BV (AL $30.4 \%$, OB $24.2 \%$ vs. BV 35.8\%). Breed differences were smaller in Sweden than in Switzerland and Austria, but still favored the local breed, SRB (SRB $42.4 \%$ vs. SH 43.4\%). In Poland, average SCC100 was above $82 \%$ in all local breeds. Here, we found lower SCC100 in the commercial PHF breed $(76.1 \%)$, which did not differ statistically from ZB (82.6\%), and the worst performance in the local breeds ZR (87.6\%) and RP (87.8\%).

\section{Veterinary Treatments}

Data on veterinary treatments were only available for Austria and Sweden. Descriptive prevalence and model results are shown in Table 5. In Austria, breeds did not differ regarding the overall percentage of cows treated by a veterinarian (AL $14.2 \%$ vs. BV 15.3\%) or percentages of cows treated for fertility or leg or claw problems, but fewer AL cows than BV cows were treated because of udder problems (AL $2.0 \%$ vs. BV $4.4 \%$ ). In Sweden, the local breed SRB had a lower 


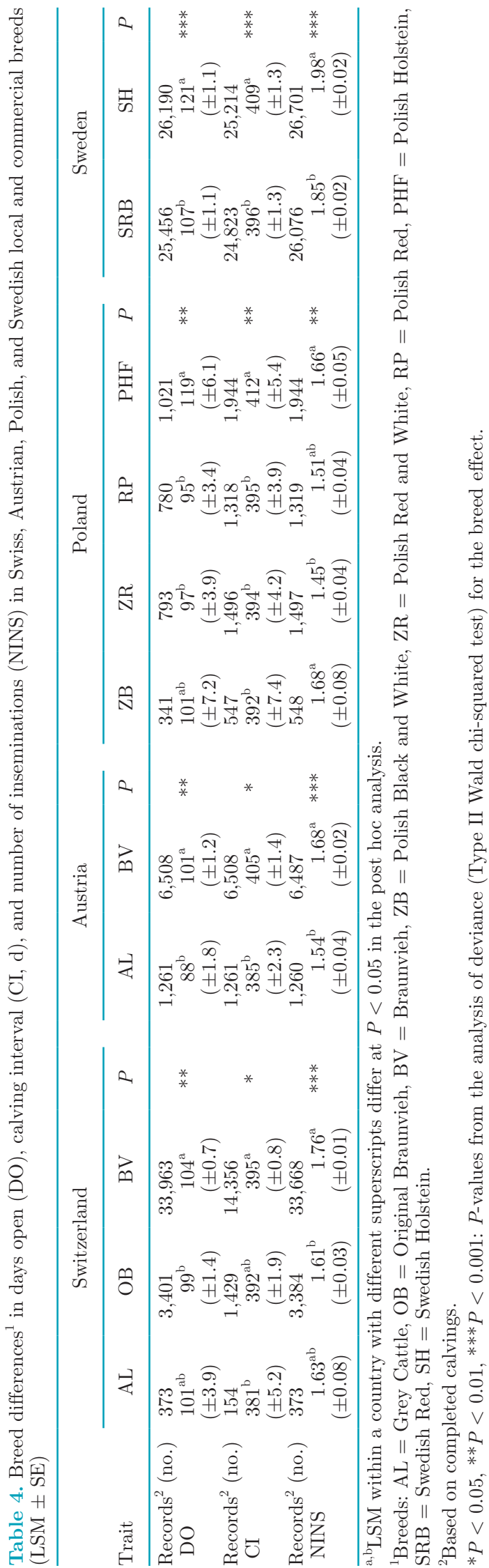

average percentage of cows treated by a veterinarian (SRB $15.6 \%$ vs. SH $21.7 \%$ ) and a lower percentage of cows treated for udder (SRB 6.8\% vs. SH 10.4\%) or fertility problems (SRB 3.9\% vs. SH 5.9\%). The local breed SRB showed lower percentages of claw or leg problems registered during regular claw trimming (SRB $14.3 \%$ vs. SH 17.3\%). The variable RECLAW did not only include veterinary treatments, explaining the higher percentage compared with the Austrian data set. Breeds did not differ regarding metabolic disorders in the Swedish data set, which were below $1 \%$ in both breeds.

\section{DISCUSSION}

\section{Milk Yield and Milk Content Traits}

We expected a higher production level in commercial breeds as reported in similar studies (e.g., Gandini et al., 2007; Spengler Neff et al., 2012; Flach et al., 2018). In our study, we focused on organic farms but aside from information on mountain grazing (in Austrian, Swiss, and Polish data) and production zones (in Swiss data), we did not have information on other variables to correct for management practice or production intensity within organic dairy systems. The differing production levels between countries in the present study may be explained by differing system intensities at the national level. For example, Krieger et al. (2017) reported that the highest level of concentrate feeding was found on organic farms in Sweden (median of $2,373 \mathrm{~kg} / \mathrm{cow}$ and year, range: $0-5,475 \mathrm{~kg}$ ), followed by Spain (median of $1,500 \mathrm{~kg} / \mathrm{cow}$ and year, range: $0-2,600 \mathrm{~kg}$ ), Germany $(1,200 \mathrm{~kg} / \mathrm{cow}$ and year, range: $0-3,667 \mathrm{~kg})$, and France (median of $616 \mathrm{~kg} /$ cow and year, range: $0-1,900 \mathrm{~kg}$ ). However, the aim of the current study was to compare breeds within countries, not between countries.

Higher milk yields in dairy cows go along with higher shares of human-edible food being fed to ruminants (Zehetmeier et al., 2012), thus contradicting the organic ideal of regional nutrient cycles with low-import proportions (IFOAM, 2014). In Switzerland, the yearly proportion of concentrates on organic dairy farms managed according to Bio Suisse standards must not exceed $10 \%$ of DM (Bio Suisse, 2018), a standard stricter than any other country included in this study, explaining the medium to low average milk yield compared with that of Sweden. In Poland, poor conditions over decades, especially regarding nutrition of heifers and cows, is partly responsible for the low average milk yield of the local breed Polish Red Cattle (Szarek et al., 2004). Because of unavailability of data, we did not correct ECM for metabolic BW. This might have reduced the gap 
Table 5. Descriptive mean proportions and LSM $( \pm \mathrm{SE})$ of cows treated due to any reason, cows treated due to udder, fertility and metabolic problems, as well as claw treatments (Austria) and remarks from claw trimming (Sweden) for Austrian and Swedish breeds ${ }^{1}$ at lactation level (number of lactations shown in parentheses below breed)

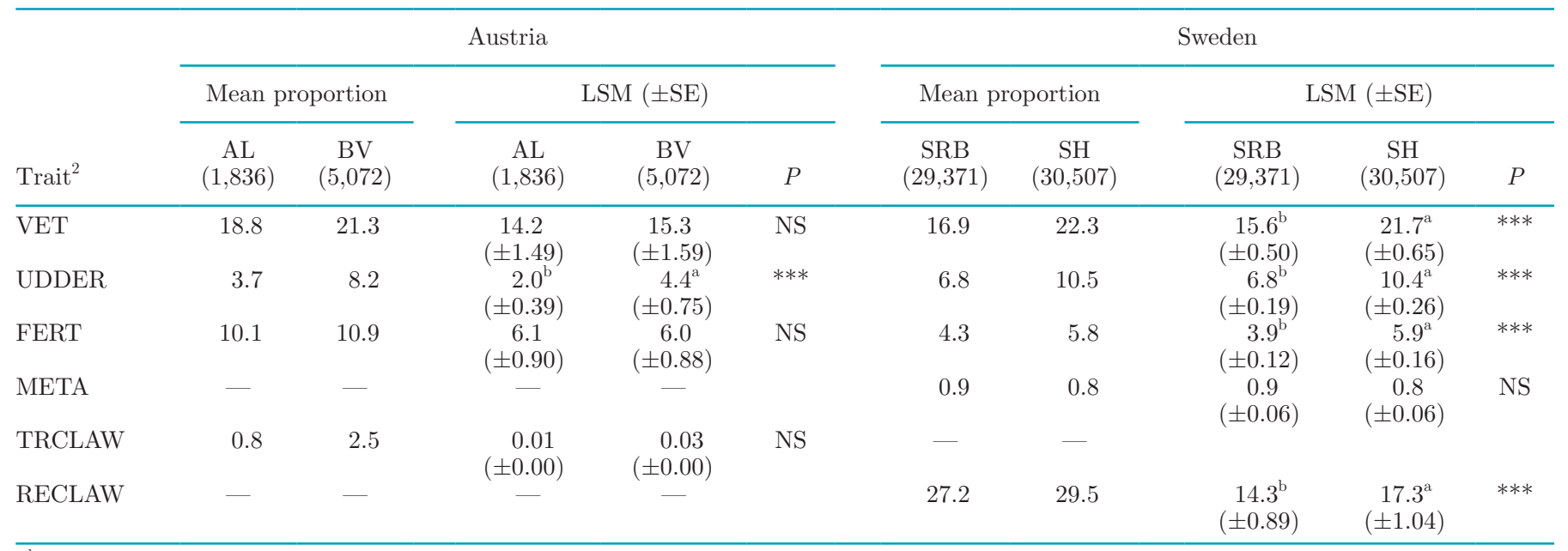

${ }^{\mathrm{a}, \mathrm{b}} \mathrm{LSM}$ within a country with different superscripts differ at $P<0.05$ in the post hoc analysis.

${ }^{1} \mathrm{AL}=$ Grey Cattle, BV $=$ Braunvieh, $\mathrm{SRB}=$ Swedish Red, $\mathrm{SH}=$ Swedish Holstein.

${ }^{2}$ All traits were binary coded (yes/no) at the lactation level; VET = occurrence of any veterinary treatment during lactation, UDDER $=$ veterinary treatment of udder problems, FERT = veterinary treatment of fertility problems, META = veterinary treatment of metabolic diseases, TRCLAW = veterinary claw treatment, RECLAW = remark on claw problem during claw trimming.

*** $P<0.001: P$-values from the analysis of deviance (Type II Wald chi-squared test) for the breed effect.

between commercial and local breeds in favor of the latter, as shown by Horn et al. (2013).

Results on breed comparisons regarding milk constituents reported in the literature are as inconsistent as our findings (Walsh et al., 2008; Horn et al., 2013; Piccand et al., 2013). One explanation for inconsistency regarding milk constituents could be that, aside from breed, feeding has a pronounced effect on milk fat and protein content (e.g., Leiber et al., 2004), and breeds might not be equally distributed over feeding systems and production intensities in our study. One indication for this is that shares of lactations achieved under mountainous pasturing conditions differed considerably between breeds within country (not applicable to Sweden), as presented in Table 1. We assume that farms with and without mountainous pasturing also differ in terms of general management practices and production intensities.

\section{Relevance of Longevity and Dual-Purpose Breeds in Terms of Sustainability}

Our findings regarding a longer productive lifespan in local dairy breeds are supported by some studies (e.g., Gandini et al., 2007; Walsh et al., 2008), whereas other researchers did not find breed differences in longevity (Haiger and Knaus, 2010). In accordance with our findings for Austria, ZuchtData (2016) reported a longer productive lifespan for AL than for BV (4.69 and 3.87 lactations, respectively) in 2015. Our results might be explained in part by antagonistic genetic correlations between high yield and productive life as reported by Pritchard et al. (2013) in HF cows. However, the breed effect on average lifetime may well be confounded with an effect of system intensity, which is obvious, for example, when data from low-input systems are compared with the national average (Leiber et al., 2017).

According to Ahlman et al. (2011, 2014), longevity is especially important in organic production because it combines all functional traits. It affects the sustainability of dairy production at different levels because a short productive lifespan means that investment into rearing has to be paid off in a shorter period of time (economic sustainability) and implies more greenhouse gas emissions per kilogram of product (environmental sustainability; Bergeå et al., 2016). An Austrian study on organic dairy cows highlighted the economic relevance of longevity by showing that cows reached their maximum annual milk yield in the fifth lactation and their peak annual profit in the sixth lactation (Horn et al., 2012).

The relevance of increasing the length of productive life in dairy cows for the sake of environmental sustainability is underlined by the fact that $\mathrm{CH}_{4}$ emission per unit of intake, BW, and milk yield in dairy cows has been reported to increase in the first few lactations but is lower in cows around $6.5 \mathrm{yr}$ of age onward (Grandl et al., 2016). 
Moreover, the combination of beef and dairy production, either by siring more dairy cows with beef breeds or by using dual-purpose breeds, is advantageous in terms of greenhouse gas emissions per unit of product compared with specialized systems producing the same amount of milk and beef separately (Zehetmeier et al., 2012). Because many of the local breeds considered in our study are dual-purpose breeds, their value for the organic sector in terms of sustainability should also be assessed against this background.

\section{Lactation Persistency}

Our findings on milk persistency in Switzerland are similar to that in the Swiss BV and OB populations reported by the breeding organization in 2014 (82 and $84 \%$, respectively; Schwarzenberger, 2014). In contrast, Horn et al. (2013) did not detect breed differences in persistency when comparing Brown Swiss cows primarily selected for high milk yield with an HF strain selected for lifetime performance and fitness over several decades. We could not find other studies comparing persistency between local and commercial breeds, which is remarkable because we assume the trait to be relevant for roughage-based dairy systems.

\section{Fertility as an Indicator for Robustness}

Better fertility in local breeds has been reported in other studies (e.g., Gandini et al., 2007; Spengler Neff at al., 2012; Horn et al., 2013; Curone et al., 2016), although some did not find differences in the number of services per pregnancy (Gandini et al., 2007; Walsh et al., 2008).

Our results might be explained by the antagonistic genetic correlations between reproductive traits and milk yield, as reviewed by Berry et al. (2014). Nevertheless, it seems advisable to critically evaluate studies that report an association between level of milk production and fertility, because they may be based on incomplete or biased data sets by failing to include other important factors for poor fertility such as nutrition, management, and environmental factors (Rauw et al., 1998; LeBlanc, 2010). Our data on the whole organic subpopulation did not allow us to correct for differing production intensities, so we cannot exclude a bias on fertility records.

In accordance with Friggens et al. (2017), who defined robustness of animals as "the ability, in the face of environmental constraints, to carry on doing the various things that the animal needs to do to favour its future ability to reproduce," we conclude that local breeds have good robustness, because they not only show better fertility performance but also better longevity.
SCC

Our findings of higher SCC levels in commercial breeds support earlier findings of lower SCC levels in local breeds (e.g., Vyletelova-Klimesova et al., 2014; Curone et al., 2018). However, other studies did not reveal such differences (Horn et al., 2013; Piccand et al., 2013). In addition to breed differences in SCC levels, Curone et al. (2018) found differing metabolic pathways between breeds and reported a more pronounced systemic inflammatory response in terms of positive acute phase markers postpartum for Holstein Friesian compared with Rendena cows. Although the authors admit that their results need further validation on larger animal cohorts, this may suggest that breed differences exist regarding metabolism in dairy cows.

At the national level, our Swiss results were similar to those found by Spengler Neff et al. (2012), reporting lower SCS in pure OB cows than in BV in Switzerland. The average SCC level in our Swedish data is in line with the median prevalence of subclinical mastitis of 44.1\% (range 18.9-80.6\%) on organic Swedish farms reported by Krieger et al. (2017). Genetic antagonism between milk yield and SCC or mastitis as reported in the literature (e.g., reviewed by Martin et al., 2018) might explain the more favorable situation in the loweryielding local breeds in the Swiss, Austrian, and Swedish data sets.

Using a strict threshold for subclinical mastitis in our study, the low average levels of SCC100 found in Austria and Switzerland demonstrate that other European countries have potential to improve their udder health situation. The very high overall percentage of records with elevated SCC in Poland may be explained in part by the fact that the proportion of older animals is high in this country ( 40 to $45 \%$ of local breeds in $\geq$ fourth lactation) and SCS levels have been reported to increase with lactation number (Bielfeldt et al., 2004).

\section{Veterinary Treatments}

With regard to the ranking of treatment reasons, our findings are similar to other studies on health status of organic dairy herds. For example, Krieger et al. (2017) reported a median prevalence of $51.3 \%$ for subclinical mastitis, $42 \%$ for prolonged calving interval, and $14.2 \%$ for clinical lameness on 192 organic dairy farms in Germany, Spain, France, and Sweden.

Results on the association between the increase of milk yield over the last decades and health traits are controversial (e.g., Ingvartsen et al., 2003; LeBlanc, 2010). Nevertheless, it seems that higher milk yield is associated with a greater risk for cows to suffer from 
mastitis, ketosis, and leg problems (reviewed by Rauw et al., 1998), as well as fertility problems (Knaus, 2009).

Horn et al. (2013) found no breed differences regarding ketosis, parturient paresis, retained placenta, or ovarian disorders over a 4-yr study period under experimental organic farming conditions in Austria comparing the Brown Swiss performance strain with HF selected for longevity; however, they reported a higher mastitis incidence for Brown Swiss during the study period.

A recent study in Denmark showed a herd-level prevalence of hoof and leg diseases for Holstein cows of $7 \%$ on organic farms (Slagboom et al., 2016). Our figures in Sweden were higher because of a differing trait definition, which for our data included all remarks during claw trimming. Prevalence of udder diseases for organic SH is 19\% in Denmark (Slagboom et al., 2016), which is higher than the $10.5 \%$ in our study and, in that study, prevalence of reproduction diseases (10\%) was nearly twice the rate we found, which might be because we reported based on binary-coded data.

The percentage of treated cows in our Austrian data set was lower than the prevalence reported by EggerDanner et al. (2012) across all dairy breeds for 2010, which ranged from 13.5 to $17.0 \%$ for udder disorders, from 14.5 to $28.1 \%$ for reproductive disorders, and from 3.3 to $5.1 \%$ for hoof and claw disorders, depending on the data registration method applied. Breed differences between $\mathrm{BV}$ and $\mathrm{AL}$ regarding disease frequency were generally higher in the national Austrian data set in 2015, which included both organic and conventional farms; for example, $24.0 \%$ of BV cows had been treated because of fertility problems compared with $11.1 \%$ of the AL cows (C. Egger-Danner, ZuchtData EDVDienstleistungen GmbH, Vienna, Austria, unpublished data). Among possible reasons for the disagreements compared with our findings are diverging trait definitions and our restrictions of the data set to organic farms that had continuous health monitoring during the study period. A comparison of our findings with those reported by Egger-Danner et al. (2012) is difficult because of our binary coding, which reduces the values reported here.

Our findings regarding treatments of fertility problems approximately match those of another study that reported a median treatment incidence per cow and year of 3 to $8 \%$ for fertility disorders on 37 organic farms in Austria (Ivemeyer et al., 2012).

\section{CONCLUSIONS}

We conclude that the lower production level of local breeds is at least partly compensated for by their pronounced, although not fully consistent, advantages in fertility, health status, and longevity found across 4 European countries. Local breeds are worth considering for their particular robustness, which is expressed by their better fertility and longevity. Because the use of local dual-purpose breeds offers the possibility of combining meat and milk production, thus potentially reducing greenhouse gas emissions for the same quantity of product per unit compared with specialized systems, we consider the use of local dual-purpose breeds a means of achieving greater sustainability in the organic sector and other roughage-based production systems.

\section{ACKNOWLEDGMENTS}

This study was conducted within the project OrganicDairyHealth funded by the ERA-Net CORE Organic Plus program (Tjele, Denmark). Funders on national level within the scope of the CORE Organic Plus program were the Austrian Federal Ministry for Sustainability and Tourism (BMNT; Vienna, Austria; grant number: BMLFUW-LE.1.3.2/0002-PR/8/2015 for Switzerland, and project numbers: 101056 and 101060 for Austria), the Swedish Research Council for Environment, Agricultural Sciences and Spatial Planning (FORMAS; Stockholm, Sweden) and the Polish National Centre for Research and Development (Warsaw, Poland), and the Polish Ministry of Agriculture and Rural Development (grant number: CoreOrganicPlus/ORGANICDAIRYHEALTH/141/IZPIB/2015; Warsaw, Poland). We thank Bio Suisse (Basel, Switzerland) and Qualitas AG (Zug, Switzerland), ZuchtData EDV-Dienstleistungen GmbH (Vienna, Austria) and ZAR-Federation of Austrian Cattle Breeders (Vienna, Austria), SYMLEK owned by the National Animal Breeding Centre (Warsaw, Poland) and Växa Association (Uppsala, Sweden) for providing the data and valuable suggestions, and Christian Stricker from agn Genetics GmbH (Davos, Switzerland) for validation of Swiss, Austrian, and Polish data sets.

\section{REFERENCES}

Ahlman, T., B. Berglund, L. Rhydhmer, and E. Strandberg. 2011. Culling reasons in organic and conventional dairy herds and genotype by environment interaction for longevity. J. Dairy Sci. 94:1568-1575. https://doi.org/10.3168/jds.2010-3483.

Ahlman, T., M. Ljung, L. Rydhmer, H. Röcklinsberg, E. Strandberg, and A. Wallenbeck. 2014. Differences in preferences for breeding traits between organic and conventional dairy producers in Sweden. Livest. Sci. 162:5-14. https://doi.org/10.1016/j.livsci.2013.12 .014 .

Bapst, B., A. Bieber, and E. Haas. 2005. Untersuchungen zur Zuchtstrategie in Schweizer Bio-Braunviehbetrieben. Pages 395398 in Ende der Nische-Beiträge zur 8. Wissenschaftstagung Ökologischer Landbau, Kassel, Germany. Kassel Univ. Press, Kassel, Germany. 
Bates, D., M. Maechler, B. Bolker, and S. Walker. 2015. Fitting linear mixed-effects models using lme4. J. Stat. Softw. 67:1-48. https:// doi.org/10.18637/jss.v067.i01.

Bergeå, H., A. Roth, U. Emanuelson, and S. Agenäs. 2016. Farmer awareness of cow longevity and implications for decision-making at farm level. Acta Agric. Scand. 66:25-34. https://doi.org/10.1080/ 09064702.2016.1196726.

Berry, D. P., E. Wall, and J. E. Pryce. 2014. Genetics and genomics of reproductive performance in dairy and beef cattle. Animal 8:105-121. https://doi.org/10.1017/S1751731114000743.

Bett, R. C., K. Johansson, E. Zonabend, B. Malmfors, J. Ojango, A. M. Okeyo, and J. Philipsson. 2010. Trajectories of evolution and extinction in the Swedish cattle breeds. Abstract number P 0583 in Proc. 9th World Congr. Genet. Appl. Livest. Prod., Leipzig, Germany. Gesellschaft für Tierzuchtwissenschaften e. V., Gießen, Germany.

Bielfeldt, J. C., R. Badertscher, K.-H. Tölle, and J. Krieter. 2004. Factors influencing somatic cell score in Swiss dairy production systems. Schweiz. Arch. Tierheilkd. 146:555-560. https://doi.org/ 10.1024/0036-7281.146.12.555

Bio Suisse. 2018. Guidelines for the Production, Processing and Trade of Bud Products. Part II: Guidelines for Plant Production and Animal Husbandry in Switzerland. Bio Suisse, Basel, Switzerland.

Bytyqi, H., G. Klemetsdahl, J. Ødegård, H. Mehmeti, and M. Vegara. 2005. A comparison of the productive, reproductive and body condition score traits of the Simmental, Brown Swiss and Tyrol Grey breeds in smallholder herds in Kosovo. Agri 37:9-20.

Coleman, J., D. P. Berry, K. M. Pierce, A. Brennan, and B. Horan. 2010. Dry matter intake and feed efficiency profiles of 3 genotypes of Holstein-Friesian within pasture-based systems of milk production. J. Dairy Sci. 93:4318-4331. https://doi.org/10.3168/jds.2009 -2686 .

Coleman, J., K. M. Pierce, D. P. Berry, A. Brennan, and B. Horan. 2009. The influence of genetic selection and feed system on the reproductive performance of spring-calving dairy cows, within future pasture-based production systems. J. Dairy Sci. 92:5258-5269. https://doi.org/10.3168/jds.2009-2108.

Curone, G., J. Filipe, P. Cremonesi, E. Trevisi, M. Amadori, C. Pollera, B. Castiglioni, L. Turin, V. Tedde, D. Vigo, P. Moroni, A Minuti, V. Bronzo, M. F. Addis, and F. Riva. 2018. What we have lost: Mastitis resistance in Holstein Friesians and in a local cattle breed. Res. Vet. Sci. 116:88-98. https://doi.org/10.1016/j .rvsc.2017.11.020.

Curone, G., M. Zanini, S. Pansere, C. Colombani, P. Moroni, F. Riva, and M. Faustini. 2016. Milk ketone bodies assessment in a local Italian cow breed (Modense) versus Holstein and characterization of its physiological, reproductive and productive performances. Int. J. Environ. Agric. Res. 2:15-22.

EC. 2007. Council Regulation (EC-No 834/2007) of 28 June 2007 on organic production and labelling of organic products and repealing Regulation (EEC) No 2092/91. Off. J. L198:1-23.

Egger-Danner, C., B. Fuerst-Waltl, W. Obritzhauser, C. Fuerst, H. Schwarzenbacher, B. Grassauer, M. Maierhofer, and A. Koeck. 2012. Recording of direct health traits in Austria- Experience report with emphasis on aspects of availability for breeding purposes. J. Dairy Sci. 95:2765-2777. https://doi.org/10.3168/jds.2011 -4876 .

Flach, L., S. Kühl, C. Lambertz, and M. Gauly. 2018. Effekt verschiedener Kraftfutterintensitäten auf Tierwohl und Tiergesundheit in der Milchviehhaltung im Bergebiet. Abstract number D 21 in DGfZ-/GfT- Gemeinschaftstagung 2018, Bonn, Germany. Institut für Tierwissenschaften, Rheinische Friedrich-WilhelmsUniversität, Bonn, Germany.

Friggens, N. C., F. Blanc, D. P. Berry, and L. Puillet. 2017. Review: Deciphering animal robustness. A synthesis to facilitate its use in livestock breeding and management. Animal 11:2237-2251. https: //doi.org/10.1017/S175173111700088X

Fuerst-Waltl, B., C. Fuerst, W. Obritzhauser, and C. Egger-Danner. 2016. Sustainable breeding objectives and possible selection response: Finding the balance between economics and breeders' pref- erences. J. Dairy Sci. 99:9796-9809. https://doi.org/10.3168/jds .2016-11095.

Gandini, G., C. Maltecca, F. Pizzi, A. Bagnato, and R. Rizzi. 2007. Comparing local and commercial breeds on functional traits and profitability. The case of Reggiana dairy cattle. J. Dairy Sci. 90:2004-2011. https://doi.org/10.3168/jds.2006-204.

Grandl, F., S. L. Amelchanka, M. Furger, M. Clauss, J. O. Zeitz, M. Kreuzer, and A. Schwarm. 2016. Biological implications of longevity in dairy cows: 2. Changes in methane emissions and efficiency with age. J. Dairy Sci. 99:3472-3485. https://doi.org/10.3168/jds .2015-10262

Hagger, C. 2005. Estimates of genetic diversity in the brown cattle population of Switzerland obtained from pedigree information. J. Anim. Breed. Genet. 122:405-413. https://doi.org/10.1111/j.1439 $-0388.2005 .00552 . x$.

Haiger, A., and W. Knaus. 2010. Vergleich von Fleckvieh und Holstein Friesian in der Milch- und Fleischleistung. 1. Mitteilung: Milchleistungsvergleich ohne Kraftfutter. Zuchtungskunde 82:131-143.

Hamann, J. 2005. Diagnosis of mastitis and indicators of milk quality. Pages 82-90 in Mastitis in Dairy Production: Current Knowledge and Future Solutions. H. Hogeveen, ed. Wageningen Academic Publishers, Wageningen, the Netherlands. https://doi.org/ 10.3920/978-90-8686-550-5.

Heller, D., and V. Potthast. 1990. Successful Feeding of Dairy Cattle 2nd ed. DLG-Verlag, Frankfurt am Main, Germany.

Horn, M., W. Knaus, L. Kirner, and A. Steinwidder. 2012. Economic evaluation of longevity in organic dairy cows. Org. Agric. 2:127143. https://doi.org/10.1007/s13165-012-0027-6.

Horn, M., A. Steinwidder, J. Gasteiner, L. Podstatzky, A. Haiger, and W. Zollitsch. 2013. Suitability of different dairy cow types for an Alpine organic and low-input milk production system. Livest. Sci. 153:135-146. https://doi.org/10.1016/j.livsci.2013.01.011.

IFOAM. 2014. The IFOAM Norms for Organic Production and Processing. International Federation of Organic Agriculture Movements (IFOAM), Bonn, Germany.

Ingvartsen, K. L., R. J. Dewhust, and N. C. Friggens. 2003. On the relationship between lactational performance and health: Is it yield or metabolic imbalance that cause production diseases in dairy cattle? A position paper. Livest. Prod. Sci. 83:277-308. https:// doi.org/10.1016/S0301-6226(03)00110-6.

Ivemeyer, S., J. Brinkmann, S. March, C. Simantke, C. Winckler, and U. Knierim. 2018. Major organic dairy farm types in Germany and their farm, herd, and management characteristics. Org. Agric. 8:231-247. https://doi.org/10.1007/s13165-017-0189-3.

Ivemeyer, S., G. Smolders, J. Brinkmann, E. Gratzer, B. Hansen, B. I. F. Henriksen, J. Huber, C. Leeb, S. March, C. Mejdell, P. Nicholas, S. Roderick, E. Stoeger, M. Vaarst, L. K. Whistance, C. Winckler, and M. Walkenhorst. 2012. Impact of animal health and welfare planning on medicine use, herd health and production in European organic dairy farms. Livest. Sci. 145:63-72. https://doi.org/ 10.1016/j.livsci.2011.12.023.

Kelm, S. C., and A. E. Freeman., and NC-2 Technical Committee. 2000. Direct and correlated responses to selection for milk yield: Results and conclusions of regional project NC-2: 'Improvement of dairy cattle through breeding, with emphasis on selection'. J. Dairy Sci. 83:2721-2732. https://doi.org/10.3168/jds.S0022 $-0302(00) 75166-6$.

Knaus, W. 2009. Dairy cows trapped between performance demands and adaptability. J. Sci. Food Agric. 89:1107-1114. https://doi .org/10.1002/jsfa.3575.

Krieger, M., K. Sjöström, I. Blanco-Penedo, A. Madouasse, J. E. Duval, N. Bareille, C. Fourichon, A. Sundrum, and U. Emanuelson. 2017. Prevalence of production disease related indicators in organic dairy herds in four European countries. Livest. Sci. 198:104-108. https://doi.org/10.1016/j.livsci.2017.02.015.

LeBlanc, S. 2010. Assessing the association of the level of milk production with reproductive performance in dairy cattle. J. Reprod. Dev. 56(Suppl.):S1-S7.

Leiber, F., M. Kreuzer, B. Jörg, H. Leuenberger, and H.-R. Wettstein. 2004. Contribution of altitude and Alpine origin of forage to the 
influence of Alpine sojourn of cows on intake, nitrogen conversion, metabolic stress and milk synthesis. Anim. Sci. 78:451-466.

Leiber, F., I. K. Schenk, A. Maeschli, S. Ivemeyer, J. O. Zeitz, S. Moakes, P. Klocke, P. Staehli, C. Notz, and M. Walkenhorst. 2017. Implications of feed concentrate reduction in organic grasslandbased dairy systems: A long-term on-farm study. Animal 11:20512060. https://doi.org/10.1017/S1751731117000830.

Lenth, R. V. 2016. Least-Squares Means: The R package lsmeans. J. Stat. Softw. 69:1-33. https://doi.org/10.18637/jss.v069.i01.

Macdonald, K. A., G. A. Verkerk, B. S. Thorrold, J. E. Pryce, J. W. Penno, L. R. McNaughton, L. J. Burton, J. A. S. Lancaster, J. H. Williamson, and C. W. Holmes. 2008. A comparison of three strains of Holstein-Friesian grazed on pasture and managed under different feed allowances. J. Dairy Sci. 91:1693-1707. https://doi .org $/ 10.3168 /$ jds.2007-0441.

Marley, C. L., R. F. Weller, M. Neale, D. C. J. Main, S. Roderick, and R. Keatinge. 2010. Aligning health and welfare principles and practice in organic dairy systems: A review. Animal 4:259-271. https://doi.org/10.1017/S1751731109991066.

Martin, P., H. W. Barkema, L. F. Brito, S. G. Narayana, and F. Miglior. 2018. Symposium review: Novel strategies to genetically improve mastitis resistance in dairy cattle. J. Dairy Sci. 101:27242736. https://doi.org/10.3168/jds.2017-13554.

Nauta, W. J., T. Baars, H. Saatkamp, D. Weenink, and D. Roep. 2009. Farming strategies in organic dairy farming: Effects on breeding goal and choice of breed. An explorative study. Livest. Sci. 121:187-199. https://doi.org/10.1016/j.livsci.2008.06.011.

Nauta, W. J., A. F. Groen, R. F. Veerkamp, D. Roep, and T. Baars. 2005. Animal breeding in organic dairy farming: An inventory of farmers' views and difficulties to overcome. NJAS 53:19-34. https: //doi.org/10.1016/S1573-5214(05)80008-9.

Olesen, I., A. F. Groen, and B. Gjerde. 2000. Definition of animal breeding goals for sustainable production systems. J. Anim. Sci. 78:570-582. https://doi.org/10.2527/2000.783570x.

Oltenacu, P. A., and D. M. Broom. 2010. The impact of genetic selection for increased milk yield on the welfare of dairy cows. Anim. Welf. 19:39-49.

PFHBiPM. 2018. Polish Federation of Cattle Breeders and Dairy Farmers. Breeds. Accessed Sep. 20, 2018. http://pfhb.home.pl/ www/english/index.php?strona=breeds.htm.

Piccand, V., E. Cutullic, S. Meier, F. Schori, P. L. Kunz, J. R. Roche, and P. Thomet. 2013. Production and reproduction of Fleckvieh, Brown Swiss, and 2 strains of Holstein-Friesian cows in a pasturebased, seasonal-calving dairy system. J. Dairy Sci. 96:5352-5363. https://doi.org/10.3168/jds.2012-6444.

Pritchard, T., M. Coffey, R. Mrode, and E. Wall. 2013. Genetic parameters for production, health, fertility and longevity traits in dairy cows. Animal 7:34-46. https://doi.org/10.1017/ S1751731112001401.

R Core Team. 2016. R: A language and environment for statistical computing. R Foundation for Statistical Computing, Vienna, Austria. https://www.R-project.org/.
Rauw, W. M., E. Kanis, E. N. Noordhuizen-Stassen, and F. J. Grommers. 1998. Undesirable side effects of selection for high production efficiency in farm animals: A review. Livest. Prod. Sci. 56:1533. https://doi.org/10.1016/S0301-6226(98)00147-X.

Schwarzenberger, M. 2014. Persistenz- der Spiegel im Stall. CHbraunvieh $7: 4-7$.

Signer-Hasler, H., A. Burren, M. Neuditschko, M. Frischknecht, D. Garrick, C. Stricker, B. Gredler, B. Bapst, and C. Flury. 2017. Population structure and genomic inbreeding in nine Swiss dairy cattle populations. Genet. Sel. Evol. 49:83. https://doi.org/10 .1186/s12711-017-0358-6.

Simianer, H., ed. 2007. Ökologische Milchviehzucht: Entwicklung und Bewertung züchterischer Ansätze unter Berücksichtigung der Genotyp x Umwelt-Interaktionen und Schaffung eines Informationssystems für nachhaltige Zuchtstrategien. Final Report. Accessed Aug. 12, 2018. http://orgprints.org/11222//.

Slagboom, M., M. Kargo, D. Edwards, A. C. Sørensen, J. R. Thomasen, and L. Hjortø. 2016. Organic dairy farmers put more emphasis on production traits than conventional farmers. J. Dairy Sci. 99:9845-9856. https://doi.org/10.3168/jds.2016-11346.

Spengler Neff, A., D. Mahrer, J. Moll, A. Burren, and C. Flury. 2012. Analyses of different brown cattle breeds and their crosses in Switzerland. Page 148 in Book of Abstracts of the 63rd Annu. Mtg. Eur. Fed. Anim. Sci., Bratislava, Slovakia. Wageningen Academic Publishers, Wageningen, the Netherlands.

Stiglbauer, K. E., K. M. Cicconi-Hogan, R. Richert, Y. H. Schukken, P. L. Ruegg, and M. Gamroth. 2013. Assessment of herd management on organic and conventional dairy farms in the United States. J. Dairy Sci. 96:1290-1300. https://doi.org/10.3168/jds .2012-5845.

Szarek, J., K. Adamczyk, and A. Felenczak. 2004. Polish Red Cattle breeding: past and present. Anim. Genet. Resour. 35:21-35. https: //doi.org/10.1017/S1014233900001784.

Växa Sverige. 2015. Cattle statistics, 2015. Accessed Dec. 8, 2018. http://www.vxa.se/fakta/styrning-och-rutiner/mer-om-mjolk.

Vyletelova-Klimesova, M., O. Hanus, A. Dufek, I. Nemckova, J. Horacek, A. Ponizil, and L. Nejeschlebova. 2014. Staphylococcus aureus and other pathogens in relation to breed of cattle and somatic cell count. Bulg. J. Agric. Sci. 20:1495-1500.

Walsh, S., F. Buckley, K. Pierce, N. Byrne, J. Patton, and P. Dillon. 2008. Effects of breed and feeding system on milk production, body weight, body condition score, reproductive performance and postpartum ovarian function. J. Dairy Sci. 91:4401-4413. https:// doi.org/10.3168/jds.2007-0818.

Zehetmeier, M., J. Baudracco, H. Hoffmann, and A. Heißenhuber. 2012. Does increasing milk yield per cow reduce greenhouse gas emissions? A system approach. Animal 6:154-166. https://doi .org/10.1017/S1751731111001467.

ZuchtData. 2016. ZuchtData-Jahresbericht 2016. Accessed Sep. 24, 2018. http://www.zar.at/Downloads/Jahresberichte/ZuchtData -Jahresberichte.html. 